\title{
Management of Crown Rot of Cucumber (Fusarium solani) through Integrated Practices and Organic Amendments
}

\author{
Deepika Nehra*, R.R. Ahir and Lalita Lakhran \\ Department of Plant Pathology, S.K.N. Agriculture University, Jobner, Jaipur, India \\ *Corresponding author
}

\section{Keywords}

Cucumber, Crown rot, Mustard cake, Neem

\section{Article Info}

Accepted:

20 June 2020

Available Online:

10 July 2020

\section{A B S T R A C T}

Crown rot of cucumber (Cucumis sativum) caused by Fusarium solani. The present investigations carried out the All combination i.e. Benomyl + Trichoderma harzianum, Trichoderma harzianum + Neem cake and Benomyl + Neem cake were found effective to reduce disease incidence of crown rot of cucumber over check at 40 and 60 days after sowing. Among the all treatments combination of Benomyl + Trichoderma harzianum (15.62 and 22.22\%) was found superior followed by Benomyl + Neem cake (21.87 and $28.00 \%$ ) at 40 and 60 days, respectively and soil application of organic amendments. All the organic manure tested reduce crown rot incidence in cucumber significantly over check. Neem cake was most effective to reduce incidence of crown rot in cucumber over all other treatments with minimum disease incidence (18.75 and $23.07 \%$ at 40 and 60 days respectively) followed by mustard cake (21.87 and 24.00 at 40 and 60 days respectively to reduce incidence of crown rot in cucumber.

\section{Introduction}

Cucumber (Cucumis sativum L.) belongs to family Cucurbitaceae. In hindi cucumber is known as "Kheera". Cucumber is a widely cultivated plant of gourd in cucurbites. It is a popular and widely cultivated vegetable in India. It is a creeping vine that bears cucumiform fruit used as vegetable. Cucumber is used as salad or as vegetable. In
India, cucumber is commonly grown in Karnataka, Andhra Pradesh, Assam, Odisha, Punjab and Rajasthan, generally towards the riversides. Rajasthan state provides the maximum potential for the production of cucumber because of it has agro-climatic conditions that are best suited for their growth and yield. According to De Candole (1967) cucumber is an indigenous vegetable of India. Purseglove (1969) has suggested that all 
cultigens (Cucumis sativus L.) originated from northern India where the related Cucumis hardwicki Royle occurs as wild, although this might be a "wild" form of Cucumis sativus, which has escaped from cultivation. Cucumber has been cultivated in India for at least three thousand years (Rai and Yadav, 2005).

It is a warm season crop and grows best at a temperature between $18^{\circ} \mathrm{C}$ to $24^{\circ} \mathrm{C}$. It is a short duration (90 -100 days) crop (Kumar et al., 2015). Cucumber is rich in vitamin B and $\mathrm{C}$ as well as in minerals such as calcium, phosphorus, iron and potassium. It contains an organic substance called cucurbitacin (Bhattacharya et al., 2015). Soil inoculation, seed inoculation and seedling inoculation was reported to best method of pathogencity for the root rot or wilt diseasecausingfungi in crop plant (Shivpuri and Bansal, 1987 and Sinha and Prasad, 1989).

Li et al., (2010) was first reported crown rot of cucumber caused by Fusarium solani causing yellowing and wilting of the leaves of grafted cucumber in greenhouse in china. Symptoms consisted of dark brown, water soaked lesion and dense mycelial mat at the base of the stem

Management strategies of this disease include a large range options but farmers largely depends on fungicides due to its higher control efficiency over other methods. However, wider use of fungicides can cause hazards to human health and known to increase environmental pollution. Therefore, to off sate this negative impact, alternative eco-friendly approaches for control of crown rot of cucumber are needed. Looking to the importance of this crop and severity of this disease in the vicinity of Jobner, the present studies was carried out to reduce the losses caused by crown rot of cucumber with the suitable eco-friendly management practices.

\section{Materials and Methods}

\section{Efficacy of organic amendments against crown rot of cucumber (In pot condition)}

The experiment was carried out in earthen pots 9 x 12 inches. The organic manure (Neem cake, Mustard cake, Cotton cake, Groundnut cake and Castor cake) were thoroughly mixed as per recommended dose of nitrogen supplied by manure in each pot @ 10 per cent (w/w) of soil before 1 month of sowing (Lumsden et al., 1983). The inoculum was added @ $20 \mathrm{~g}$ in each pot and mixed thoroughly up to 5-7 $\mathrm{cm}$ depth in the pot. In each pot 10 surface sterilized seeds were sown. Surface sterilized seed sown without organic manure with inoculated pot served a check. Four replication of each treatment was maintained. Light watering was given at regular interval in each pot to maintain proper moisture levels. Observations were recorded on 40 and 60 days.

\section{Integrated management of crown rot of cucumber (In pot condition)}

The most effective treatments viz., organic amendment (neem cake) through soil application, seed treatment with fungicides (benomyl) and bio agents (Trichoderma viride) in combination with each other were evaluated to see their combined effect on crown rot incidence. Neem cakes mixed with unsterilized soil contained in earthen pots were allowed to decompose for a week. The pots were then inoculated with Fusarium solani@20 g/pot and under polythene cover for few days. After 7 day of inoculation seed of cucumber treated with requisite quantity of fungicide and bioagent were sown in pots. Five replications for each treatment were maintained. A control treatment without any amendments and sown with untreated seeds was also kept for comparison. The pots were watered as when required. All the pots were 
maintained under identical condition. Observation on crown rot incidence of cucumber plants was recorded on 40 and 60 DAS.

\section{Results and Discussion}

Efficacy of organic amendments against crown rot of cucumber as soil application (In vivo)

The data of Table 1 represent that all the organic manure tested reduce crown rot incidence in cucumber significantly over check. Neem cake was found most effective to reduce incidence of crown rot in cucumber over all other treatments with minimum disease incidence (18.75 and $23.07 \%$ at 40 and 60 days respectively) followed by mustard cake (21.87 and 24.00 at 40 and 60 days respectively). Cotton cake (31.25 and $36.36 \%$ at 40 and 60 days respectively) was found least effective to reduce incidence of crown rot in cucumber.

Maximum disease control was observed in Neem cake (18.75 and $23.07 \%$ ) followed by mustard cake (21.87 and $24.00 \%)$ over check (59.37 and $61.53 \%)$ at 40 and 60 days after sowing, respectively. (Table 1) All the organic manure tested reduce crown rot incidence in cucumber significantly over check. Neem cake was most effective to reduce incidence of crown rot in cucumber over all other treatments with minimum disease incidence. Yelmame et al., (2010), tested the extracts of different organic cakes viz. of neem cake, mustard cake, FYM, groundnut cake, poultry manure, press mud, castor cake and coconut cake against Fusarium solani by Poisoned Food Technique in vitro, in which least growth of pathogen was recorded by the neem cake $(59.80 \%)$ showing excellent inhibitory effect followed by mustard cake (52.61\%). Jat et al., (2017) studied on the relative efficacy of organic cakes against coriander wilt caused by Fusarium oxysporum under field conditions. Neem cake was found most effective with 58.95\% disease control followed by Mustard cake.

\section{Integrated management of crown rot of cucumber (In vivo)}

The biocontrol agent (Trichoderma harzianum) as seed treatment, fungicide (Benomyl) as seed treatment and organic amendment (Neem cake) as soil treatment were found superior in in vitro and in vivo condition against crown rot of cucumber were combined each other and tested in vivo condition against crown rot of cucumber.

The results present in Table 2 revealed that all combination i.e. Benomyl + Trichoderma harzianum, Trichoderma harzianum + Neem cake and Benomyl + Neem cake were found effective to reduce disease incidence of crown rot of cucumber over check at 40 and 60 days after sowing. Among the all treatments combination of Benomyl + Trichoderma harzianum (7.62 and 9.22\%) was found superior followed by Benomyl + Neem cake (10.87 and $13.00 \%)$ at 40 and 60 days, respectively. Trichoderma harzianum + Neem cake (15.13 and $19.13 \%)$ was found least effective against crown rot of cucumber at 40 and 60 days, respectively.

Maximum disease control was found with Benomyl + Trichoderma harzianum (86.45 and $84.81 \%$ ) followed by Benomyl + Neem cake (80.67 and $78.56 \%$ ) over check at 40 and 60 days, respectively. Minimum disease control was found with Trichoderma harzianum + Neem cake (73.10 and 68.48\%) (Table 2). Although Trichoderma harzianum is sensitive to Benomyl at higher doses but it is tolerant at lower doses (Sharma and Dureja, 2004 and McLean et al., 2001). 
Table.1

\begin{tabular}{|l|l|c|c|}
\hline S. No. & Name of organic amendments & Quantity/ pot & Quantity/ha \\
\hline 1. & Neem cake & $25 \mathrm{~g}$ & $8 \mathrm{t} / \mathrm{ha}$ \\
\hline 2. & Castor cake & $30 \mathrm{~g}$ & $10 \mathrm{t} / \mathrm{ha}$ \\
\hline 3. & Mustard cake & $30 \mathrm{~g}$ & $10 \mathrm{t} / \mathrm{ha}$ \\
\hline 4. & Groundnut cake & $30 \mathrm{~g}$ & $10 \mathrm{t} / \mathrm{ha}$ \\
\hline 5. & Cotton cake & $30 \mathrm{~g}$ & $10 \mathrm{t} / \mathrm{ha}$ \\
\hline
\end{tabular}

Table.2 Combination of bio-agent, organic amendment and fungicide(in vivo)

\begin{tabular}{l|l|}
\hline S.No. & \multicolumn{1}{|c}{ Treatments } \\
\hline 1. & Seed treatment with Trichoderma harzianum @ 4g/kg seed + Benomyl @0.0 2g/kg seed. \\
\hline 2. & $\begin{array}{l}\text { Seed treatment with Trichoderma harzianum @ 4g/kg seed +soil application with Neem } \\
\text { cake@ 25g/pot }\end{array}$ \\
\hline 3. & Soil application with Neem cake@ 25g/pot + seed treatment with Benomyl @ 0.02g/kg seed. \\
\hline 4. & Control (untreated) \\
\hline
\end{tabular}

Table.1 Efficacy of organic amendments against crown rot of cucumber (as soil application) in pot conditions

\begin{tabular}{|l|l|c|c|c|c|}
\hline S.No. & Treatment & \multicolumn{2}{|c|}{ \% Disease incidence } & \multicolumn{2}{c|}{ \% Disease control } \\
\hline $\mathbf{1}$ & & $\mathbf{4 0}$ DAS & $\mathbf{6 0}$ DAS & 40 DAS & 60 DAS \\
\hline & Neem cake & 18.75 & 23.07 & 68.41 & 62.50 \\
\hline $\mathbf{2}$ & Castor cake & $(25.66)$ & $(28.71)$ & & \\
\hline $\mathbf{3}$ & & 28.12 & 34.78 & 52.63 & 43.47 \\
\hline $\mathbf{4}$ & Mustard cake & $(32.02)$ & $(36.14)$ & & \\
\hline & Groundnut cake & 21.87 & 24.00 & 63.16 & 60.99 \\
\hline $\mathbf{5}$ & Cotton cake & $25.88)$ & $(29.33)$ & & \\
\hline & & $(30.00)$ & $(32.68)$ & 57.89 & 52.60 \\
\hline $\mathbf{6}$ & Control & $(33.25$ & 36.36 & 47.36 & 40.96 \\
\hline & & 59.37 & $(37.08)$ & & \\
\hline & SEm \pm & $(50.40)$ & $(51.53$ & - & - \\
\hline & CD $(\mathbf{P}=\mathbf{0 . 0 5})$ & $\mathbf{1 . 2 2}$ & $\mathbf{1 . 3 0}$ & & \\
\hline
\end{tabular}

*Average of four replications

Figures given in parentheses are angular transformed values 
Table.2 Integrated management of crown rot of cucumber (In pot conditions)

\begin{tabular}{|c|c|c|c|c|c|}
\hline \multirow[t]{2}{*}{ S.No } & \multirow[t]{2}{*}{ Treatment } & \multicolumn{2}{|c|}{$\%$ disease incidence } & \multicolumn{2}{|c|}{ \% Disease control } \\
\hline & & 40 DAS & 60 DAS & 40 DAS & 60 DAS \\
\hline \multirow[t]{2}{*}{1} & \multirow{2}{*}{$\begin{array}{l}\text { Benomyl }+ \text { Trichoderma harzianum (as } \\
\text { seed treatment) }\end{array}$} & 7.62 & 9.22 & 86.45 & 84.81 \\
\hline & & $(16.02)$ & $(17.68)$ & & \\
\hline \multirow[t]{2}{*}{2} & \multirow{2}{*}{$\begin{array}{l}\text { Trichoderma harzianum (as seed } \\
\text { treatment) + Neem cake (as soil treatment) }\end{array}$} & 15.13 & 19.13 & 73.10 & 68.48 \\
\hline & & $(22.89)$ & $(25.94)$ & & \\
\hline \multirow[t]{2}{*}{3} & \multirow{2}{*}{$\begin{array}{l}\text { Benomyl (as seed treatment) + Neem cake } \\
\text { (as soil treatment) }\end{array}$} & 10.89 & 13.00 & 80.67 & 78.56 \\
\hline & & $(19.27)$ & $(21.13)$ & & \\
\hline \multirow[t]{4}{*}{4} & \multirow[t]{2}{*}{ Control } & 56.25 & 60.71 & - & - \\
\hline & & $(48.59)$ & $(51.18)$ & & \\
\hline & SEm \pm & 0.99 & 1.13 & & \\
\hline & $\mathrm{CD}(\mathbf{P}=\mathbf{0 . 0 5})$ & 3.06 & 3.47 & & \\
\hline
\end{tabular}

*Average of five replications

Figures given in parentheses are angular transformed values

All combination i.e. Benomyl + Trichoderma harzianum, Trichoderma harzianum + Neem cake and Benomyl + Neem cake were found effective to reduce disease incidence of crown rot of cucumber over check at 40 and 60 days after sowing. Among the all treatments combination of Benomyl + Trichoderma harzianum (15.62 and 22.22\%) was found superior followed by Benomyl + Neem cake (21.87 and $28.00 \%)$ at 40 and 60 days, respectively.

Jat and Ahir (2017) were worked on the effect of combinations of different fungicides and organic amendments against Fusarium solani in vivo conditions. Benomyl + Neem cake combination was found most effective with minimum percent disease incidence $(12.00 \%)$ followed by Thiophanate methyl + Neem cake $(16.00 \%)$. Yadav et al., (2014) observed the effect of combinations of fungicides and organic amendments against basal rot of onion caused by Fusarium oxysporum in pot conditions. Benlate + Neem cake was found most effective with minimum (13.00\%) disease incidence followed by Bavistin + Neem cake $(16.00 \%)$ and Benlate + Mustered cake (19.00\%). Tu (1987) studied the control of disease of green pea i.e.
Fusarium wilt (Fusarium oxysporum) and root rot (Fusarium solani). The contribution of each fungal component of root rot disease complex of green pea was studied and develop integrated control programme. This integrated control programme include selection of resistant varieties use of inter season green manure crops, appropriate tillage, soil indexing, use of suitable herbicides and modification of soil $\mathrm{pH}$.

It is concluded that among the five organic amendments Neem cake was observed most effective with minimum percent disease incidence of crown rot of cucumber.The combination of Benomyl + Trichoderma harzianum was found most effective with minimum percent disease incidence of crown rot followed by Benomyl + Neem cake. This integrated control programme include selection of resistant varieties use of inter season green manure crops, appropriate tillage, soil indexing, use of suitable herbicides and modification of soil $\mathrm{pH}$.

\section{References}

Bhattacharya, C., Bhattacharya, M. and Kumar, M.B. (2015). How loo is also 
cured by Cucumber and after titration also by its foam. IOSR J. of Pharmacy and Biological Sci. 10:43-48.

De Candole, A. (1967). Origin of cultivated plants, Edn. 7, Hafnar Publishing Co., New York, pp. 264.

Jat , M.K., Ahir, R.R., Choudhary, Sanju and Kakraliya, G.L. (2017). Management of coriander wilt (Fusarium oxysporum) through cultural practices as organic amendments and date of sowing. $J$. Pharama. and Phytochem. 6(5): 31-33.

Jat, M.K. and Ahir, R.R. (2017). In vitro and vivo evaluation of some fungicides and organic amendments to control of Fusarium solani causing Indian Aloe (Aloe barbadensis) root rot. International J. of Plant Sciences, 12: 90-94.

Kumar, P., Chauhan, R.K. and Grover, P.K. (2015).Comparative economics of cucumber cultivation under polyhouses and open field conditions in Haryana. Indian J. of Economics and Development, 3 (7).

Li, B.J., Liu, Y., Shi, Y. X. and Xie, X.W. (2010). First report of crown rot of grafted cucumber caused by Fusarium solani in China. Phytopathol. 94: 1377.2.

Lumsden, R.D., Lewis, J.A.J. and Millner, P.D. (1983). Effect of composted sewage sludge on several soil borne pathogens and diseases. Phytopathol., 73(11): 1543-1548 Science Letters, 2: 439-440.

McLean, K.L., Hunt, J. and Stewart, A. (2001). Compatibility of the biocontrol agent Trichoderma harzianum C52 with selected fungicides. New Zealand $\mathrm{Pl}$. Prot., 54: 84-88.

Purseglove, J.W. (1969). Tropical crops Dicotyledons. Longmans, Green and Co. Ltd., London and Harlow. 719p.

Rai, N. and Yadav, D.S. (2005).Advances in vegetables production. Research Book Centre, Delhi pp. 344-356.

Sharma, P. and Dureja, P. (2004). Evaluation of Thrichoderma harzianum and $T$. viride isolates at $\mathrm{BCA}$ pathogen crop interface. J. Mycol. Pl. Pathol., 34(1): 47-55.

Shivpuri, A. and Bansal, R.K. (1987). Fusarium wilt of Trigonella new recorded. Indian J. Mycol. and Pl. Pathol., 17: 104.

Sinha, D.C. and R.K. Prasad (1989).Seed mycoflora of fenugreek and its control. Indian Phytopathol., 42: 177-179.

Tu, J.C. (1987). Etiology and control of Fusarium wilt (Fusarium oxysporum) and root rot (Fusarium solani) of green pea (Pisum satium). Mededelingen Van de Faculteit land Bouwetenschappen Rijks Universiteit Gent, 52 (3a): 815823.

Yadav, S.L., Ahir, R.R., Rathore, B.S. and Yadav, S.M. (2014).Efficacy of different fungicides and organic amendments against basal rot of onion caused by Fusarium oxysporum in vitro Pl. Pathol. J. 13(1): 56-58.

Yelmane, M.G., Mehta, B.P., Deshmukh, A.J. and Patil, V.A. (2010). Evaluation of some organic extracts in in vitro to control Fusarium solani causing chilli wilt. Int. J. Pharma Bio Sci. 1 (2): 1920.

\section{How to cite this article:}

Deepika Nehra, R.R. Ahir and Lalita Lakhran. 2020. Management of Crown Rot of Cucumber (Fusarium solani) through Integrated Practices and Organic Amendments. Int.J.Curr.Microbiol.App.Sci. 9(07): 2373-2378. doi: https://doi.org/10.20546/ijcmas.2020.907.277 